\title{
Creating a New Experience for Tourists through City Branding (Case Study: City of Shiraz in Iran)
}

Mahshid Barani ${ }^{+}$

\section{Abstract}

The utility of the destination brand experience directly originates from the type of feelings of audiences present in a city. In this study, after recognising the components affecting the sense of place, their relationship with the tourism brand experience in the city of Shiraz, Iran was assessed, and the way the components made effects were investigated as well. To achieve this end, as stated above, this research was conducted using a case study of Shiraz city. The data collection was performed through observation and questionnaire, and the data analysis technique was a combination of quantitative (using SPSS software) and qualitative methods. The obtained results demonstrated that all factors in each form, activity and meaning components affected the sense of place in Shiraz; however, factors associated with the city's history, such as historical attractions and famous people, had a remarkable effect when compared to others. Overall, consideration of the indicators influencing the sense of place in all aspects, particularly the management and operational ones (design and execution), results in a more robust connection of the audience with the destination brand, growth of sustainable tourism in Shiraz, and successful competition in the international arena.

Keywords: Brand Experience; Sense of Place; Audience Satisfaction; Tourism; Shiraz; Iran

\footnotetext{
${ }^{+}$Corresponding Author, Faculty of Interior Architecture, Shiraz University of Arts, Adabiat Intersection, Shiraz, Iran, Postal Code: 7146696989. Email: m_barani@shirazartu.ac.ir

(C) 2021 Barani. This is an Open Access article distributed under the terms of the Creative Commons Attribution License (http://creativecommons.org/licenses/by/2.0), which permits unrestricted use, distribution, and reproduction in any medium, provided the original work is properly cited.
} 


\section{Introduction}

Destination branding has become one of the most attractive and challenging issues in place marketing and tourism marketing. The attention to the city branding and developing the mental destination image is rising. Branding initiatives are carried out in extensive areas concerning brand image management and brand experience, which are reckoned to cover a wide range of beneficiaries. Since the main activity of the tourism industry is selling experiences, the income of tourism businesses is guaranteed only by providing pleasant and exciting experiences because the experience of audiences greatly influences their satisfaction and their evaluation of a specific service (Otto and Ritchie, 1996).

In the tourism literature, researchers have also emphasised the importance of providing memorable experiences and considered tourists' experiences as their crucial source of information for decision-making regarding their revisitation from the destination (Kozak, 2001). Given the importance of the relationship between the destination brand experience and the sense of place, this study initially attempted to identify the components of the sense of place in Shiraz. Then, the effect of the components and solutions to improve and upgrade the brand experience were evaluated. To attain these objectives, the research questions were addressed as follows:

- What are the factors distinguishing the city of Shiraz from other tourism destinations?

- How is the prioritisation of factors distinguish the city of Shiraz from other tourism destinations?

- How is the effect of sense of place components on the tourism brand experience in Shiraz?

Taking these research questions, the study follows the following roadmap (Figure 1).

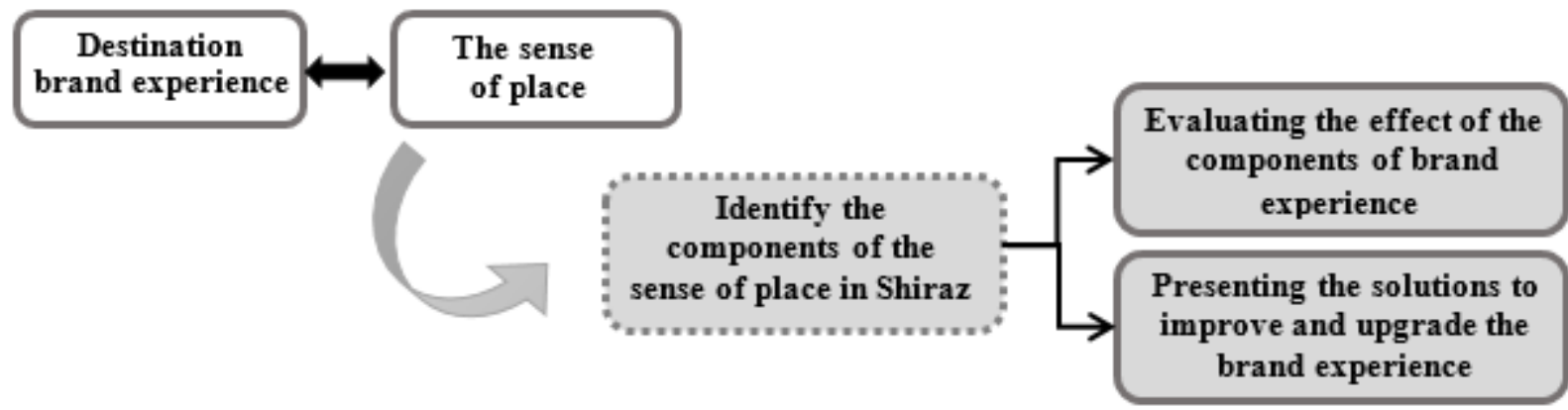

Figure 1: The Road Map of the Study

Source: The Author

\section{Literature Review}

According to existing studies, investigations on various aspects of destination branding are rising. In a study entitled "Presentation of $A$ Conceptual Model For The Impact Of Mental Image And Brand Experience of Tourism Destination On Tourists' Loyalty To Tourism Destination Brand", Haghighi Nasab et al. (2016) showed that the mental image and experience of the tourism destination brand are considered a prerequisite for satisfaction with the tourism destination, Higher satisfaction leads to the enhancement in the tourists' loyalty to the tourism destination brand. Zargham Borujeni and Behmanesh (2013) also suggested that the element of history and culture among the central resources and attractions, the aspect of cost/value among the mediating and reinforcing characteristics, and the element of hospitality among the supporting factors and resources enjoy a more influential role to create a memorable experience for cultural tourists, respectively. Kavaratzis and Ashworth (2005) pointed out the requirement of cities to create a unique and unparalleled identity in highly competitive global markets. Rainisto (2003) 
believed that place brands provide the possibility of enjoying the image value of a place. The brand of a product or service contains a unique combination of functional properties and symbolic values. In another study, Brakus et al. (2009) assessed the structure of brand experience and its development for better understanding its effect on audiences' behaviour.

Moreover, Valencia (2005) pointed out the issue from the brand management perspective. By investigating the studies carried out on the concept, it is found that the brand experience has been evaluated from different perspectives (Haji Babaei and Esmaeilpour, 2019) so that researchers have turned their focus from the definition and assessment of the structure toward the recognition of antecedents and outcomes of brand experience. Therefore, it is not surprising that a critical challenge in studies on brand experience is to experimentally prove that brand experience is not solely a secondary and unimportant concept but can forecast some concepts in the field of brand literature (Zarantonello and Schmitt, 2010).

\section{City Branding}

The term city branding is a concept similar to place marketing or spatial position and provides the position of a place (Bradley et al., 2002). The key to success in branding is the link between the brand and the consumer and the performance characteristics of the brand and symbolic values (Hankinson \& Cowking, 1993). This definition of brand and branding reflects a brand's relationship with the city marketing goals and city image management (Table 1). Same as branding, cities meet functional, symbolic, and emotional requirements, and the features fulfilling these requirements must be coordinated with the unique position of a city.

Table 1: A Summary of Definitions of City Branding from the Theorists' Perspectives

Researcher Explanation of the concept

City branding is done to establish a link between people and an image of their city, and a consistent and focused communication strategy with

Hall (2002) urban symbols. (The essential goal of city branding is to "provide a consistent and focused communication strategy").

\begin{tabular}{|c|c|}
\hline Cai (2002) & $\begin{array}{l}\text { City branding means choosing a combination of brand factors to } \\
\text { distinguish the cities by establishing a positive image. The brand factors } \\
\text { include names, terms, signs, logos, design, symbols, slogans, among } \\
\text { which name is the priority. }\end{array}$ \\
\hline Julier (2005) & City branding is considered an effort to create and enrich urban quality. \\
\hline Anholt (2006) & e identity and competition of cities. \\
\hline Rainisto (2013) & $\begin{array}{l}\text { City branding is a method to increase the city's attraction and the } \\
\text { essential factor to recognise the city's identity. }\end{array}$ \\
\hline $\begin{array}{l}\text { Judd \& Feinstei } \\
\qquad(2014)\end{array}$ & $\begin{array}{l}\text { City branding is an effort to attract tourists and a platform for sustainable } \\
\text { urban revenue and citizens' quality of life. }\end{array}$ \\
\hline
\end{tabular}

Source: Mohammadpour Zarandi and Aminian, 2015

\section{Experience and Sensations}

The terms 'experience' and 'sensation' are usually used instead of each other at first glance because the experience of a phenomenon refers to the experiences that are effective and arouse feelings. In psychology, the term 'sensations' or, generally, emotional conditions are used to refer to all the theoretical experiences said to be coupled together, i.e., experiences that are perceived in the form of goodness or badness, pleasure, or unhappiness (Norman, 2004). An experience is a multifaceted phenomenon that includes the manifestation of instinctual feelings, behavioural reactions, and intellectual and meaningful psychological reactions (Hendrik \& Hekkert, 2008). 


\section{Brand Experience}

Brand experience is a distinct concept from other concepts in the brand literature, such as brand awareness, brand image, brand attitude, brand reputation, and brand equity from the audiences' perspective. The brand experience is conceptualised as mental, internal (sensations, feelings, and cognition), and behavioural responses of the audience evoked by brandrelated stimuli, including design, identity, packaging, communications, and environments. Brand experience can be positive or negative, and more importantly, the experience affects audience satisfaction and loyalty (Zarantonello and Schmitt, 2010). Although brand experience contains different kinds of audience experiences, more attention has been recently given to its emotional, contextual, symbolic, and non-utilitarian aspects of experience (Arnould and Thompson, 2005; Brakus et al., 2009; Hulten, 2011; Zarantonello and Schmitt, 2010). Brakus et al. (2009) introduced the brand experience as a multi-dimensional structure due to the facing of a customer with brand-related stimuli, which are stored in his/her long-term memory. From their point of view, this structure consists of sensory, affective, cognitive, behavioural, and social dimensions.

The sensory dimension of brand experience emphasizes the senses of touch, taste, smell, and sight. The affective dimension refers to the inner emotions and feelings of the brand. The cognitive dimension focuses on the creative thinking of the audience and reproducing events in different ways. The behavioural dimension refers to the physical experiences, and ultimately, the social dimension refers to an individual's experiences in trying to move from individualism to collectivism and being accepted by other individuals, groups, or communities (Zarantonello and Schmitt, 2010); (Schmitt 1999); (Brakus et al., 2009).

\section{The Concept of Sense of Place}

Today, the concepts of place and sense of place are among the essential matters faced in urban spaces and are considered a challenge for a large number of urban professionals. A sense of place can be known as the people's perception of environments that have a relative or sufficient cognition of them. A sense of place in urban spaces leads to forming a special relationship between the individual and the environment (Ayashm and Mirgholami, 2016).

\section{Sense of Place from Various Perspectives}

A place is a space with meaning for an individual or a group of people. This definition is expressed as "place = space + meaning" (Harrison \& Dourish, 1996). Relph (1976: 244) states that "place is a combination of space, landscape, religion, path, other people, personal experience, caring and protecting homes and contexts." He believes that understanding a place can lead to the restoration and maintenance of existing places and the creation of new places. Christian Norberg Schulz considers the sense of place a general phenomenon with structural, spatial, and atmospheric values perceived by man via orientation identification perception. Generally speaking, a sense of place remains a dynamic fact throughout time (Partovi, 2008). The sense of place determines the nature of the place and is found in places with particular and distinct characters (Partovi, 2008).

\section{The Factors Constituting the Sense of Place}

According to Falahat (2006), about the concept of sense of place in different perspectives and various levels of sense of place, the constituent factors of the sense of place are put into three groups:

\section{Form (Physical) Factor}

From the view of Lynch, the sense of place is the factor that links human and place and creates unity, and space should have a perceptible identity and be recognisable, memorable, and visible to create a sense of place. This sense of place can also be associated with a sense of belonging (Lynch, 1997). From Norberg Schulz's (1997) perspective, the most important physical factors affecting the perception and sense of place include size, location, and degree of enclosure, contrast, scale, proportion, human scale, space, texture, colour, smell, sound, and visual diversity. 


\section{Activity Factor}

By creating meanings and supplying special activities, the physical features of an environment influence creating a sense of place. Providing space activities arises from the satisfaction of varying characteristics of the environment, such as temperature, sound, the possibility of individual activities, and social interactions by the environment's static elements like dimensions, proportions, and forms. Identifying space and having emotion is gained by understanding the meanings, symbols, formal and semantic aesthetics of space. Generally speaking, the sense of place results from human's inner connection, mental imagery, and the environmental characteristics (Falahat, 2006).

\section{Meaning Factor}

The sense of place is a complicated combination of meanings, symbols, and qualities that an individual or group consciously or unconsciously perceives from a specific space or area. The meanings and concepts decrypted by an individual after the perception of the place are among the factors creating a sense of place.

In this case, the sense of place does mean not only a feeling, or emotion, or any relationship with a particular place, but also a cognitive system and structure with which a person feels a sense of belonging to the issues, people, objects, and concepts of a place. Hence, people without a sense of place cannot live in a particular environment since the sense of place is the potential of space or place to create a special feeling to the generality of place, and with this sense, a place provides an individual's relationship with all existing concepts, people, and other matters. Thus, the place becomes a generality through which people recognise all the activities and events (Falahat, 2006).

Following the aforementioned issues, the following proposed model is analysed to investigate the relationship between the components of sense of place of a tourism destination, which creates the link between human and place, and the experience obtained from knowledge and perception of place (Figure 2).

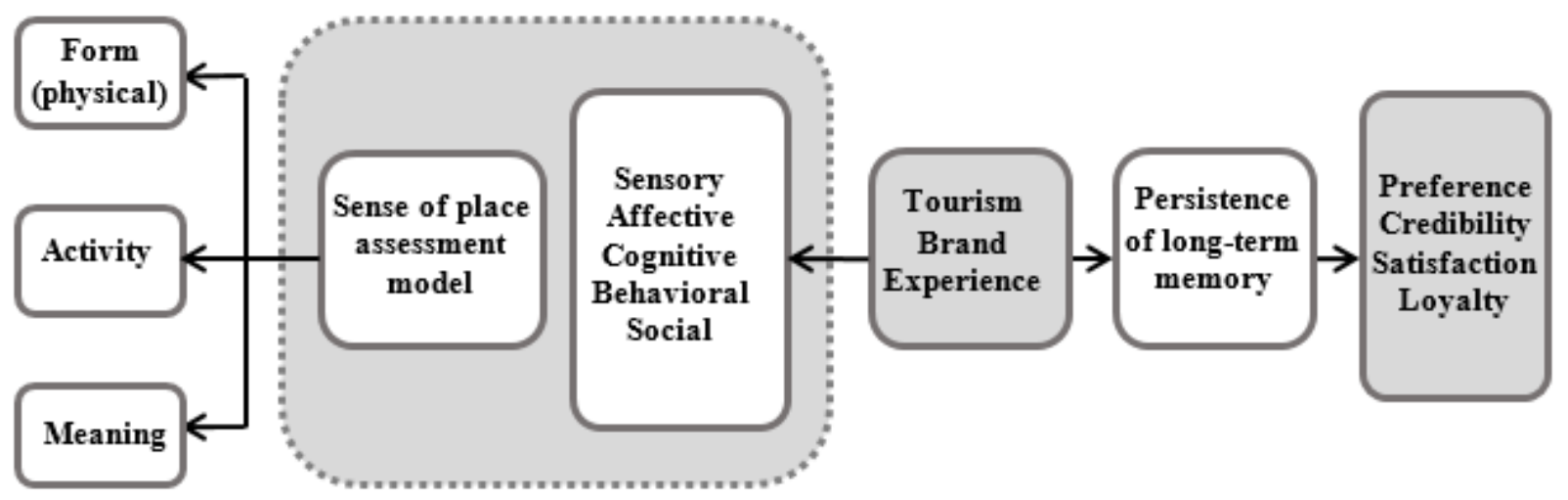

Figure 2: Conceptual Model of the Research Source: The Author

\section{Research Methodology}

The study's approach is exploratory and a combination of descriptive and survey methods and qualitative content analysis. The data have been achieved from interviews with academic experts and cognizant professionals active in the field of tourism and Shiraz studies, and the previous investigations and existing historical books. To investigate the effect of distinguishing components influencing the optimization and development of tourism in the city of Shiraz, three dimensions of the form (physical), activity, and meaning factors (independent variable) to determine the sense of place (dependent variable) in the tourism destination (Shiraz) were 
intended and included in the questionnaire. The questions were provided in the form of a Likert scale and a pairwise comparison were made between form (physical), activity, and meaning factors. The statistical population of this study consisted of 120 people, including beneficiaries and industry elements, such as the community of hoteliers, restauranteurs, tour guides, governmental activists, the City Council, Deputy of Tourism and Cultural Heritage, Handicrafts and Tourism Organisation of Shiraz. Ninety-six people participated in the questionnaire survey. The content validity of the research tools was evaluated using expert opinions. Besides, the reliability of the questionnaire was confirmed by calculating Cronbach's alpha $(\alpha=0.00)$. It is worth mentioning that all data analysis processes of the present study were performed using SPSS software.

\section{Review of the Results}

\section{Descriptive Statistics}

According to the results, among 96 people, 7.4\% were experts, $11 \%$ were designers, $10 \%$ were literature professors, while $4 \%$ were TV artists and film directors. In attention, 31\% included industry elements and beneficiaries, such as hoteliers and restauranteurs, $26 \%$ were staff of relevant governmental departments, including Cultural Heritage, Handicrafts and Tourism, tourism deputy of the City Council, and other organisations, and $8 \%$ were tour guides, respectively. Table 2 provides the gender of the subjects.

\section{Table 2: The Frequency Percentage Distribution for the Gender of the Participants in the Research}

\begin{tabular}{ccc}
\hline & Male & Female \\
\hline Number & 55 & $\mathbf{4 1}$ \\
Percentage & 57.2 & $\mathbf{4 2 . 7}$ \\
\hline Source: The Author & & \\
\hline
\end{tabular}

\section{Inferential Statistics}

Assessing the Effect of the Sense of Place Components on Tourism Destination (Shiraz)

In the first section, the participants were asked about the importance of any of the three factors (physical, activity, and meaning) in determining the sense of place of tourism destination using a questionnaire with a five-point Likert scale. Here, the results are discussed (Tables 3, 4 and 5).

Table 3: The Results of the Surveys on the Effect Size of Physical Factors Studied in

Determining the Sense of Place of Tourism Destination, Shiraz

\begin{tabular}{|cllllll}
\hline Factors & $\begin{array}{l}\text { Very } \\
\text { much } \\
\text { Frequency } \\
(\%)\end{array}$ & $\begin{array}{l}\text { Much } \\
\text { Frequency } \\
(\%)\end{array}$ & $\begin{array}{l}\text { Moderate } \\
\text { Frequency } \\
(\%)\end{array}$ & $\begin{array}{l}\text { Low } \\
\text { Frequency } \\
(\%)\end{array}$ & $\begin{array}{l}\text { Very Low } \\
\text { Frequency } \\
(\%)\end{array}$ & $\begin{array}{l}\text { Percentage } \\
\text { of } \\
\text { Responses }\end{array}$ \\
$\begin{array}{c}\text { Urban } \\
\text { Planning }\end{array}$ & $8(8.3)$ & $11(11.5)$ & $13(13.5)$ & $61(63.5)$ & $3(3.1)$ & $96(100)$ \\
$\begin{array}{c}\text { Architecture } \\
\text { Environment } \\
\text { and Climate } \\
\begin{array}{c}\text { Natural } \\
\text { Attractions }\end{array}\end{array}$ & $20(20.8)$ & $19(19.8)$ & $22(22.9)$ & $35(36.5)$ & $0(0)$ & $96(100)$ \\
$\begin{array}{c}\text { Historical } \\
\text { Attractions }\end{array}$ & $81(84.4)$ & $10(10.4)$ & $5(5.2)$ & $0(0)$ & $0(0)$ & $96(100)$ \\
$\begin{array}{c}\text { Modern } \\
\text { Attractions }\end{array}$ & $3(3.1)$ & $7(7.3)$ & $49(51)$ & $25(26)$ & $12(12.5)$ & $96(100)$ \\
\hline SOun & $58(60.4)$ & $10(10.4)$ & $3(3.1)$ & $0(0)$ & $96(100)$ \\
\hline
\end{tabular}

Source: The Author 
Table 4: The Results of the Surveys on the Effect Size of Activity Factors Studied in Determining the Sense of Place of Tourism Destination, Shiraz

\begin{tabular}{|c|c|c|c|c|c|c|}
\hline Factors & $\begin{array}{c}\text { Very Much } \\
\text { Frequency } \\
\text { (\%) }\end{array}$ & $\begin{array}{c}\text { Much } \\
\text { Frequency } \\
\text { (\%) }\end{array}$ & Moderate & $\begin{array}{l}\text { Low } \\
\text { Frequency } \\
\text { (\%) }\end{array}$ & $\begin{array}{l}\text { Very low } \\
\text { Frequency } \\
\text { (\%) }\end{array}$ & $\begin{array}{c}\text { Percentage } \\
\text { of } \\
\text { responses }\end{array}$ \\
\hline $\begin{array}{l}\text { Handicrafts and } \\
\text { Traditional Arts }\end{array}$ & $37(38.5)$ & 40 (41.7) & $15(15.6)$ & $4(4.2)$ & $0(0)$ & $96(100)$ \\
\hline Events Held & 21 (21.9) & $4(4.2)$ & $37(38.5)$ & 31 (32.3) & $3(3.1)$ & $96(100)$ \\
\hline $\begin{array}{l}\text { Destination/Place } \\
\text { Management and } \\
\text { Planning }\end{array}$ & $15(15.6)$ & $15(15.6)$ & $19(19.8)$ & 34 (35.4) & $13(13.5)$ & $96(100)$ \\
\hline $\begin{array}{l}\text { Manufactured } \\
\text { Products and } \\
\text { Goods }\end{array}$ & $11(11.5)$ & $19(19.8)$ & $36(37.5)$ & $18(18.8)$ & $12(12.5)$ & $96(100)$ \\
\hline $\begin{array}{c}\text { Famous People and } \\
\text { Figures }\end{array}$ & $77(80.2)$ & $19(19.8)$ & $0(0)$ & $0(0)$ & $0(0)$ & $96(100)$ \\
\hline
\end{tabular}

Table 5: The Results of the Surveys on the Effect Size of Meaning Factors Studied in Determining the Sense of Place of Tourism Destination Shiraz

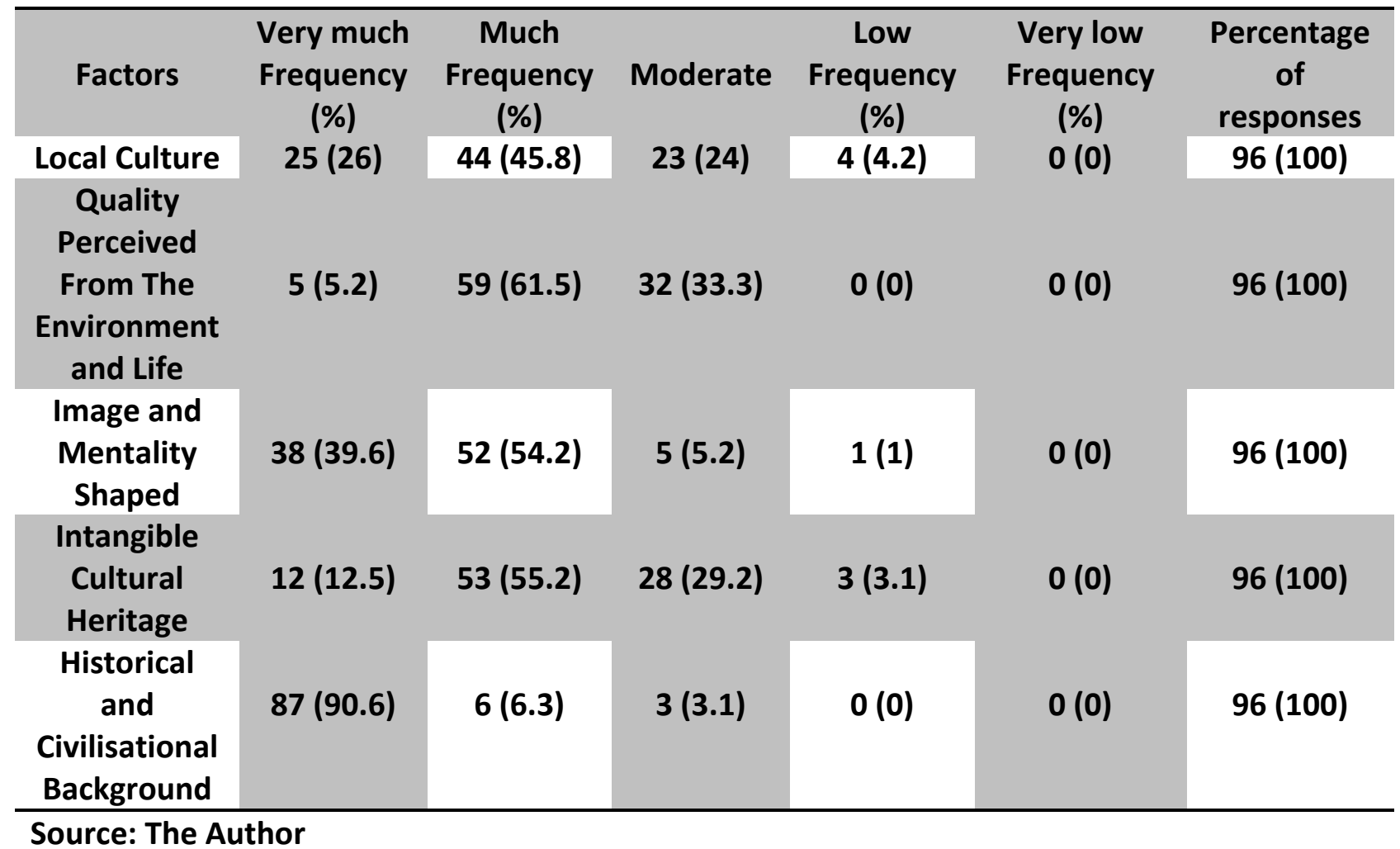

Friedman Test for Ranking Variables

To compare the mean ranks of the independent variable in this section, the Friedman nonparametric statistical test was employed. The hypotheses of the Friedman test for this study were as follows:
Null hypothesis: There is no difference between independent variables in terms of effect size. 
Hypothesis one: There is a difference between independent variables in terms of effect size.

The result of this test with the Chi-square test statistic values for each of the independent variables was equal to $243.17,162.66$, and
175.8 , respectively, at the $95 \%$ confidence; that is, it was significant at the $5 \%$ error level. Since the significance level was less than $5 \%$, hypothesis one was confirmed, which meant a difference between independent variables in terms of the effect size.

\begin{tabular}{ccc}
\hline \multicolumn{2}{c}{ Table 6: Prioritisation of Independent Variables through the Results of the Friedman Test } \\
\hline Rank & Mean Rank & Variables \\
\hline 1 & 13.43 & Historical and Civilisational Background \\
2 & 13.06 & Historical Attractions \\
3 & 12.98 & Famous People and Figures Attributed to Shiraz \\
4 & 10.77 & Image and Mentality Shaped from Shiraz \\
5 & 9.93 & Handicrafts and Traditional Arts \\
6 & 9.67 & Natural Attractions \\
7 & 9.05 & Local Culture \\
8 & 8.64 & Environment and Climate \\
9 & 8.22 & Intangible Cultural Heritage \\
10 & 7.92 & Quality Perceived from the Environment and Life \\
11 & 6.7 & Architecture \\
12 & 6.01 & Events Held \\
13 & 5.8 & Manufactured Products and Goods \\
14 & 5.4 & Destination/Place Management and Planning \\
15 & 4.27 & Modern Attractions \\
16 & 4.16 & Urban Planning \\
\hline
\end{tabular}

Source: The Author

It is apparent from Table 6 that all the factors of the form (physical), activity, and meaning components had an impact on shaping the sense of place with respect to the historical and civilisational background of Shiraz. The findings signal that the historical attractions of Shiraz, and the famous people (Hafez, Saadi, Molasadra, Vesal-e-Shirazi, etc.) and figures attributed to Shiraz had the highest impact on determining the sense of place of the tourism destination. Additionally, Shiraz's urban planning and modern attractions had the lowest impact on creating a sense of place. In connection with the influence of the sense of place components on the tourism brand experience of Shiraz, a correlation was found between the factors of the sense of place components and brand experience, which were achieved based on the emotion in sensory, affective, cognitive, behavioural, and social dimensions. Thus, the variables in the first ranks with a higher mean rank essentially had a considerable impact on creating the audience's experience of Shiraz primarily relied on factors that, in terms of meaning, physical, and activity, were linked to the historical and civilisational background of Shiraz, historical and cultural attractions, and famous people and figures of Shiraz who are globally renowned. Hence, to strengthen the brand experience in other dimensions, the cases need to be focused, gaining a lower mean ranking.

\section{Conclusion}

This study was carried out to identify Shiraz's sense of place factors and evaluate their influence on creating tourism brand experience. According to the results achieved, brand experience has a multi-dimensional structure and causes the engagement of individuals at various logical, affective, sensory, physical, and mental levels. This relationship, evoked by an audience's exposure to the city's brand-related stimuli, is stored in his/her long-term memory. 
This study indicates that numerous factors are involved in the formation of the tourism brand experience. The experience of the audience in Shiraz is often due to the presence in a culturalhistorical context that satisfies their expectations of the destination.

Moreover, famous people and figures attributed to Shiraz provoke the feelings and emotions of tourists and have a remarkable impact on the memorable experience of the destination. On the contrary, factors such as modern attractions of the city cannot have a performance like historical attractions and be among the major attractions of the destination and the essential stimuli for tourists to travel to the destination. Hence, destination management and planning with the assistance of reinforcing and moderating factors are crucial to directly influence the audience experience. The emphasis and concentration on other tourism branding components such as assessment, leadership, infrastructure, brand identity and architecture, brand conceptualisation, and word of mouth advertising also result in brand experience and loyalty to it from the audiences' perspective, and each of them can be explored in separate investigations about Shiraz and other cities.

\section{References}

Aminian N., Hassani, A. (2016). Effective factors on urban brand and their prioritization from perspective of international tourists (Case study: Tehran's Milad Tower). IUESA, 4(14), 551-591.

Anholt, S. (2006). The Anholt-GMI city brands index: How the world sees the world's cities. Place branding, 2(1), 18-31.

https://doi.org/10.1057/palgrave.pb.5990042

Aishem, M., Mirgholami, M. (2016). A conceptual model to evaluate the sense of place using four factors of perceptual, physical, social, and functional (the case study of Imam Street in Urmia, Iran). Urban Studies, 5(19), 6980.

Brakus, J. (2009). Brand Experience: What Is It? How Is It Measured? Does It Affect Loyalty. Journal of Marketing.
Cai, L. A. (2002). Cooperative branding for rural destinations. Annals of Tourism Research, 29(3), 720-742. https://doi.org/10.1016/S01607383(01)00080-9.

Eric J. Arnould, Craig J. Thompson. (2005). Consumer Culture Theory (CCT): Twenty Years of Research, Journal of Consumer Research, Volume 31, Issue 4, March 2005, Pages 868882, https://doi.org/10.1086/426626

Falahat, M. S. (2006). The concept of sense of place, and factors shaping it. Journal of Fine Arts, 26, 57-66.

https://journals.ut.ac.ir/article_12321_573ebaf d4063590e0b1c43953f8a6e63.pdf

Hajibabaei, Hossein., Esmailpur, Hassan. (2019). The Analysis of Brand Love and the Impact of Associations, Satisfaction, and Trust on Brand Love. Volume 8, Issue 4, Spring 2019, Pages 1-26.

http://dx.doi.org/10.22108/nmrj.2019.105904. 1366.

Haghighi Nasab, M., Aghaei, M., \& Nouri, F. (2016). Presentation a conceptual model on the impact of mental image and brand experience of tourism destination on tourism loyalty to tourism destination brand, International Conference on Civil, Architecture, Urban Management and Environment in The Millennium Third, Rasht, Iran.

Hall, C.M. (2002). Tourism in capital cities. Tourism: An International Interdisciplinary Journal, 50(3): 235-248.

Hankinson, G., Cowking, P. (1993). Branding in action : cases and strategies for profitable brand management. London: McGraw-Hill.

Harrison, S. Dourish, P. (1996). Re-Place-ing Space: The Roles of Space and Place in Collaborative Systems. Proc. ACM Conf. Computer-Supported Cooperative Work CSCW'96 (Boston, MA), 67--76. New York: ACM.

Heding, T., Charlotte, F., \& Bjerre, M. (2009). Brand management: Research, theory and practice (1st ed). Routledge.

Hendrik, S., Hekkert, P. (2008). Product Experience, (1st ed). Elsevier Science. 
Hultén, B. (2011). Sensory marketing: the multisensory brand-experience concept. Eur. Bus.

Rev. 23, 256-273. doi:

$10.1108 / 09555341111130245$.

Judd, D.R., Feinstein, S. (2014). The Tourist City (1st ed). Yale University Press.

Julier, G. (2005). Urban Design spaces and the Production of Aesthetic Consent, Urban Studies, Vol.42, pp.5-6, 689-888.

Kavaratzis, M., Ashworth, G. J. (2005) City Branding: An effective assertion of identity or a transitory marketing trick?. Tijdschrift voor economische en sociale geografie, 96(5), 506514.

https://doi.org/10.1057/palgrave.pb.5990056

Kozak, M. (2001). Repeaters' behaviour at two distinct destinations. Annals of Tourism Research, 28(3), 784-807. https://doi.org/10.1016/S0160-7383(00)000785

Lynch, K. (1997). A Theory of city form. (translated by Hossein Bahrain). Tehran University Press, [in Persian]

Mohammadpour Zarandi, H., Aminian, N. (2015). Evaluation of Tourism Sidewalks Recreation Potentials from the Perspective of Urban Sustainable Development (The Case Of 15 Khordad Avenue - Tehran). Journal of Urban Economics and Management, 3(11), 1-21. https://www.sid.ir/en/journal/ViewPaper.aspx? $\mathrm{id}=474126$

Norberg-Schulz, C. (1974). Meaning in western architecture. Praeger Publishers.

Norman, D. A. (2004). Emotional design: Why we love (or hate) everyday things. Basic Civitas Books.

Otto, Julie E; J.R.Brent Ritchie. (1996). The service experience in tourism, Tourism Managemen. Volume 17, Issue 3, Pages 165174. https://doi.org/10.1016/02615177(96)00003-9.

Parchekani, P. (2016). Through the Eyes of the Beholder: The Role of Culture in City Brand Architecture: A Case Study of Lyon,
France. Journal of Art and Civilization of the Orient, 4(12), 41-50.

Partovi, P. (2008). Phenomenological of place. Arts Academy of the Islamic Republic of Iran. [in Persian]

Rainisto, S. K. (2013). Success factors of place marketing: A study of place marketing practices in Northern Europe and the United States. Helsinki University of Technology.

Relph, E. (1976). Place and placelessness (Vol. 67). Pion. P: 244.

Law, R., Bai, B., Ritchie, J. B., Tung, V. W. S., \& Ritchie, R. J. (2011). Tourism experience management research. International Journal of Contemporary Hospitality Management, 23(4), $419-438$. https://doi.org/10.1108/09596111111129968.

Schmitt, B. (2009). The concept of brand experience. J Brand Manag 16, 417-419 https://doi.org/10.1057/bm.2009.5.

Shamai, S. (1991). Sense of place: An empirical measurement. Geoforum, 22(3), 347-358. https://doi.org/10.1016/0016-7185(91)90017-K

Riel, C., \& Balmer, J. M. (1997). Corporate identity: the concept, its measurement and management. European Journal of

Marketing, 31(5-6), 340-355.

https://doi.org/10.1108/eb060635.

Valencia, J.P. (2005), Experience and the Brand, London Business School - Aim Research, London.

Zargham, H., \& Behmanesh, P. (2013). Identifying factors affecting memorable tourism experience form the perspective of cultural tourists visiting Iran. Journal of Tourism Planning and Development, 2(4), 67-88.

Zarantonello, L. and Schmitt, B.H. (2010) Using the Brand Experience Scale to Profile Consumers and Predict Consumer Behavior. Journal of Brand Management, 17, 532-540. https://doi.org/10.1057/bm.2010.4

\section{Conflict of Interest}

The author bears no conflict of interest regarding the publication of this article. 


\section{Acknowledgements}

This project is a product of the research project (2019) conducted with the Director-General of Fars Province Cultural Heritage, Tourism and
Handicrafts Department. The author of this paper thanks and appreciates the efforts of all staff for their valuable guidance. 